\title{
ALLEVIATION OF ADVERSE EFFECT OF DROUGHT STRESS ON SOYBEAN (Glycine max. L.) BY USING POULTRY LITTER BIOCHAR
}

\author{
M. A. Mannan ${ }^{1 *}$, E. Halder ${ }^{1}$, M. A. Karim ${ }^{1}$ and J. U. Ahmed ${ }^{2}$ \\ ${ }^{1}$ Department of Agronomy, ${ }^{2}$ Department of Crop Botany \\ Bangabandhu Sheikh Mujibur Rahman Agricultural University, Gazipur-1706, Bangladesh \\ *Corresponding author: mannanbsmrau@yahoo.com
}

Key words: Biochar, alleviation, drought, tolerance, soybean

\begin{abstract}
The experiment was conducted under controlled condition at the Department of Agronomy, Bangabandhu Sheikh Mujibur Rahman Agricultural University, Bangladesh from January to April 2015 to clarify the mechanism that might be involved in the ameliorating effects of poultry litter biochar on soybean plants grown under water deficit stress. The treatments were (i) water regimes (well watered and 40\% field capacity) and (ii) biochar $(0,25,50$ and $100 \mathrm{t}$ $\left.\mathrm{ha}^{-1}\right)$. Results indicated that water deficit stress induced reduction in growth, leaf water and chlorophyll content and yield of soybean plant compared with those of the unstressed plants. On the other hand, water deficit stress led to increases in proline content. The improvement of drought tolerance resulted from biochar application were accompanied with improved water and proline accumulation as well as less degradation of chlorophyll in leaf was observed. These results clearly demonstrate that harmful effect of drought could reduce on plant height, leaf water and chlorophyll contents and yield of soybean. Consequently, application of poultry litter biochar is a good strategy to effectively solve the seasonal drought stress problem in dry lands.
\end{abstract}

\section{Introduction}

Drought is the most severe abiotic stress factor limiting plant growth and crop production (Moussa, 2011; Rohbakhsh, 2013). Drought stress is characterized by reduction of water content, diminished leaf water potential and turgor loss, closure of stomata and decrease in cell enlargement and growth. Severe water stress may result in the arrest of photosynthesis, disturbance of metabolism and finally the death of plant (Jaleel et al., 2008). Drought stress inhibits cell enlargement more than cell division. It reduces plant growth by affecting various physiological and biochemical processes, such as photosynthesis, respiration, translocation, ion uptake, carbohydrates, nutrient metabolism and growth promoters (Farooq et al., 2008). It affects both elongation and expansion growth (Anjum et al., 2003; Bhatt \& Rao, 2005; Kusaka et al., 2005; Shao et al., 2008) which ultimately affects the yield of plants.

Biochar is pyrolysed organic material intended for use as a soil amendment to sustainably sequester $\mathrm{C}$ and concurrently improve soil function, while avoiding any adverse effects, on both the short and long terms (Lehmann and Joseph, 2009). In recent years, application of 'biochar' has been increasingly discussed as a mitigation strategy for sequestering recalcitrant carbon into agricultural soils, which can, at the same time, improve soil fertility (Glaser et al., 2002; Lehmann, 2006). Experimental evidence so far shows that incorporation of biochar to soil enhanced soil water-holding capacity (Asai et al., 2009; Laird et al., 2010; Karhu et al., 2011), improved soil water permeability (Asai et al., 2009), improved saturated hydraulic conductivity (SHC) (Asai et al., 2009), reduced soil strength (Chan et al., 2007, 2008; Busscher et al., 2010), modification in soil bulk density ( $\rho$ b) (Laird et al., 2010) and modified 
Mannan et al.

aggregate stability (Busscher et al., 2010; Peng et al., 2011). Due to its physical properties, BC help increase water holding capacity and reduces nutrient leaching. Biochar is very porous which increases adsorption properties allowing a greater retention of water and nutrients in the soil solution (Adams et al., 2013). One greenhouse study found that the water holding capacity nearly doubled when 15\% poultry litter $\mathrm{BC}$ by weight was added to $9 \mathrm{~kg}$ of sandy loam soil. The ability to retain a relatively large quantity of water aids plant growth when under water stress. In another greenhouse study, Artiola et al. (2012) was found that soil amended with $2 \%$ and $4 \% \mathrm{BC}$ by weight (15 kg of loamy sand used) had higher yields than control plants after undergoing water stress. Biochar can be an important tool to increase food security and cropland diversity in areas with severely depleted soils, scarce organic resources, and drought prone areas. The addition of biochar to sandy soil changes soil characteristics such as its texture and porosity. Hypothetically, finer textured soils (after biochar addition) in arid climates should be associated with more negative plant and soil water potentials during drought, inducing a greater resistance of xylem to cavitation, and shallower root systems than coarse soils. The aim of this study was to investigate the poultry litter biochar effects on growth, physiology and yield of soybean plant under well water and low water availability.

\section{Materials and Methods}

The experiment was carried out at Bangabandhu Sheikh Mujibur Rahman Agricultural University, Gazipur, Bangladesh from January to April 2015. The semi controlled polythene house pot experiment was designed as a completely randomized experiment with 4 replicates, with sufficient (well watered) or reduced water ( $40 \%$ field capacity) supply and 0 (control), 25, 50 and $100 \mathrm{t} \mathrm{ha}^{-1}$ poultry litter biochar application rates. The soil was a sandy loam with $\mathrm{pH}(6.93)$, total $\mathrm{N}(0.07 \%)$, available $\mathrm{P}(0.08 \mathrm{mg}$ $\left.100 \mathrm{~g}^{-1}\right)$, exchangeable $\mathrm{K}\left(0.79 \mathrm{cmol}_{\mathrm{c}} \mathrm{kg}^{-1} \mathrm{dry}\right.$ soil), available $\mathrm{S}(10 \mathrm{ppm})$, organic carbon (0.61\%), CEC (13.05 $\mathrm{cmol}_{\mathrm{c}} \mathrm{kg}^{-1} \mathrm{dry}$ soil) and EC $0.4 \mathrm{dS} \mathrm{m}$. The pots were made from commercial polyethylene pipes with three draining holes at bottom. Each of the 24 pots (inner diameter $24 \mathrm{~cm}$, height $30 \mathrm{~cm}$ ) was filled with air-dried soil or soil and biochar mixture. For biochar treatments, 122, 244 and $488 \mathrm{~g}$ dry biochar were added per pot and thoroughly mixed with the soil, equivalent to 25,50 and $100 \mathrm{t}$ biochar $\mathrm{ha}^{-1}$, respectively. Thus, the soil surface in the biochar-amended pots was 4-7 cm higher than in the control pots. The biochar had been produced from poultry litter by pyrolysis in biochar stove. The average residence time was 5 hours and the temperature range was $300-350^{\circ} \mathrm{C}$. Fifteen (15) kg dry poultry litter was pyrolysed each time and produced $3.5 \mathrm{~kg}$ biochar on an average. The $\mathrm{pH}$, total nitrogen and available phosphorus of biochar were $6.93,1.65 \%$ and $31.81 \mathrm{ppm}$, respectively. Exchangeable $\mathrm{K}$ (meq $100 \mathrm{~g}^{-1}$ biochar), Ca (meq $100 \mathrm{~g}^{-1}$ biochar), Mg (meq $100 \mathrm{~g}^{-1}$ biochar) and Sulphur (ppm) were 3.6, 10.08, 2.75 and 870.70, respectively. The water holding capacity (WHC) of the soil- biochar mixtures was determined by submerging the entire pots for $24 \mathrm{~h}$, and subsequent draining for another $24 \mathrm{~h}$ and it was about 28\% moisture at field capacity (FC). K-value was determined to calculate the weight of the air-dried soil or soil biochar mixture at $100 \%$ field capacity. Weight of each individual empty pot was measured. Amount of the air dried soil and soil and biochar mixture of each individual pot was measured by deducting the weight of the empty pot. Then oven dry weight of this soil was measured by multiplying the K-value. Weight of the air dried soil and soil biochar mixture at $100 \%$ field capacity was measured. Then amount of water at $80 \%$ field capacity and $40 \%$ field capacity of that soil and soil biochar mixture was measured. Then pot weight was measured at $80 \%$ field capacity and $40 \%$ field capacity. Ten seeds of soybean var. BARI Soybean-6 were sown into each pot. After 14 days, 
Biochar

when seedlings had trifoliate stage six uniform and healthy plants were kept. The amount of water at $80 \%$ and 40\% FC were chosen as "well watered" and "drought stress" treatment, respectively. However, since plants showed severe wilting symptoms, the "drought stress" treatment was adjusted to 40\% FC. Afterwards, the pots were weighed every 1 to 2 days, the respective water loss was recorded, and water was applied to achieve the desired target $80 \%$ and $40 \%$ of the FC. Data on plant height, relative water, proline, chlorophyll $\mathrm{a}$, chlorophyll $\mathrm{b}$ and total chlorophyll contents in leaf, pod plant ${ }^{-1}$, seed pod $^{-1}$, 100- seed weight and yield plant ${ }^{-1}$ were recorded. The data recorded on different parameters were statistically analyzed with the help of MSTAT-C program and the difference between the treatments means were compared by LSD test (Gomez and Gomez, 1984).

\section{Results and discussions}

Plant height: Results in Fig.1 showed that drought stress decreased plant height significantly as compared with well watered plants. Plant height reduction was 20.35\% due to water stress when no biochar was applied in soil. This finding is in agreement with the results of Nielsen and Nelson (1998) and Shenkut and Brick (2003) who reported on depression of plant height as a result of severe influence from environmental factors such as water stress. Application of biochar in soil caused significant increases in plant height as compared with drought stressed plants and well watered plants. Plant height increased significantly by application of poultry litter biochar in soil both in well water and water stress conditions compare to no biochar condition. Under water stress condition plant height increased 3.30\%, 6.07\% and $4.03 \%$ by application of biochar 25,50 and $100 \mathrm{t} \mathrm{ha}^{-1}$, respectively compared to without biochar treatment. Hogan (2011) observed that biochar usually has the potential of activating soil micro organisms and increasing the water retention capacity of the soil thereby increasing photosynthetic rate and consequent increase in height of plants.

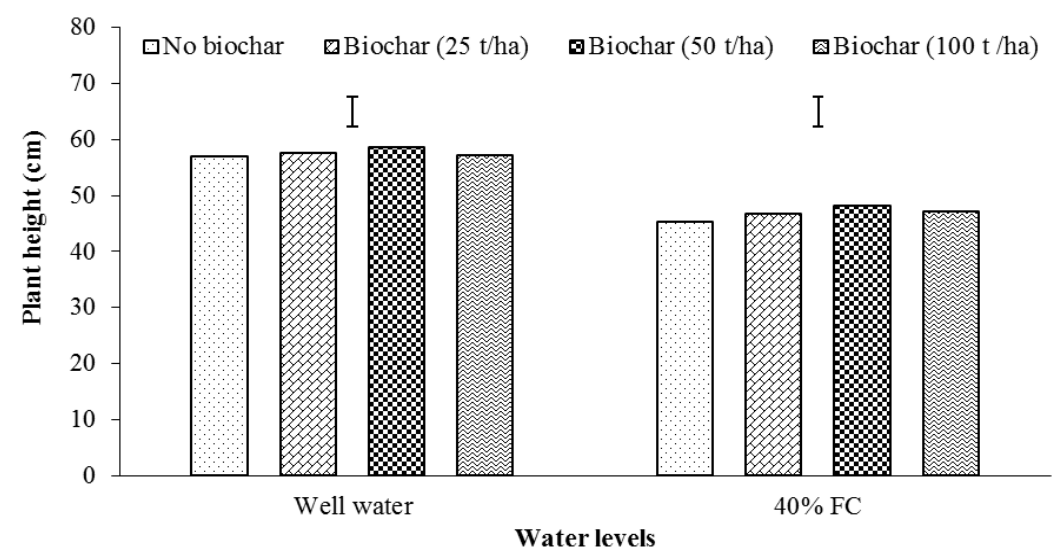

Fig. 1. Effect of poultry litter biochar on plant height under well watered and drought conditions. Bars indicates LSD at 5\% level.

\section{Relative water content}

Limited soil water always significantly impacted the plant physiological parameters 
Mannan et al.

including the relative water content. Drought stress reduced relative water content by $7.32 \%$ in soybean leaf (Fig. 2). This result is in agreement with Siddique et al. (2001) and they found that water-stressed wheat and rice plants had lower relative water content than non-stressed ones. However, biochar addition supported the plants at both water regimes. Relative water content increased by addition of biochar both in well water and water stress conditions. In well water condition relative water content increased 3.83, 5.25 and $3.51 \%$ and in water stress condition it was 4.35, 6.81 and $4.92 \%$ by addition of biochar 25, 50 and $100 \mathrm{t} \mathrm{ha}^{-1}$, respectively. In line with the findings of Gaskin et al. (2010), biochar addition also increased the overall accumulation of osmotic active substances such as $\mathrm{K}^{+}$in the plant tissues, likely due to its large cation content, leading to an improved plant water uptake which ultimately increased water content in leaf.

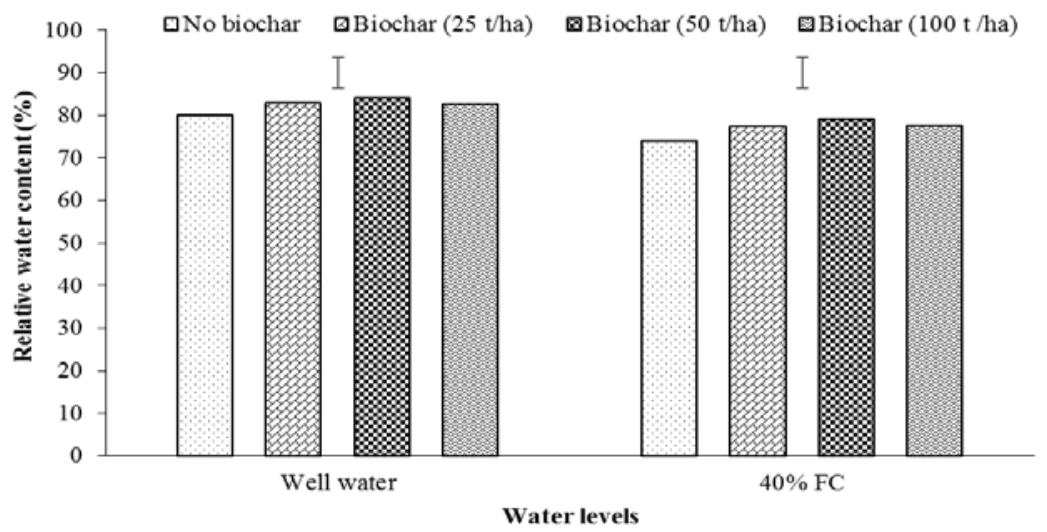

Fig. 2. Effects of poultry litter biochar on relative water content under well watered and drought conditions. Bars indicates LSD at $5 \%$ level.

\section{Chlorophyll content}

Drought stress caused significant decrease in chlorophyll $a, b$ and total photosynthetic pigments in leaves of soybean plant as compared with control plants (Table 1). Similar results are reported by Ladjal et al. (2000); Younis et al. (2000) and Terzi et al. (2010) in some soybean species and this pigment were sensitive to increasing environmental stress. The decrease in these pigments may have resulted from a decrease in leaf water status in the soybean. Abass and Mohamed (2011) who reported that photosynthetic pigments contents in leaves of common bean plants were highly significantly decreased with increasing the level of drought stress. The reduction in chlorophyll content under drought stress has been considered a typical symptom of oxidative stress and may be the result of pigment photo-oxidation and chlorophyll degradation. The decrease in the photosynthetic activity under drought stress may be due to stomatal or non-stomatal mechanisms. Stomata closure is one of the first responses to drought stress which result in declined rate of photosynthesis. The drought induced reduction in the chlorophyll content could be attributed to loss of chloroplast membranes, excessive swelling, and distortion of the lamellae vesiculation and the appearance of lipid droplets. Addition of biochar in soil increased chlorophyll content under well water and stress conditions although it was not significant in case of chlorophyll a and total chlorophylls. In well water condition total chlorophyll content increased by 3.31, 3.12, $1.56 \%$ and water stress condition it was 7.25, 29, $17 \%$ when biochar application rate was 25,50 and $100 \mathrm{t} \mathrm{ha}^{-1}$, respectively. Highest increased of chlorophyll content was found under water stress condition when soil was 
Alleviation of Adverse Effect of Drought Stress on Soybean (Glycine max. L.) By Using Poultry Litter

Biochar

treated with biochar @ 50 t ha ${ }^{-1}$. Lehmann et al (2006) reported that application of biochar in Triticum aestivum $\mathrm{L}$ not only improve the availability of nutrients but also promote vegetative growth by improving the photosynthetic pigments Chlorophyll $(\mathrm{a}, \mathrm{b}$ and total) under stressed condition.

Table 1. Effects of poultry litter biochar on chlorophyll $a$, chlorophyll $b$ and total chlorophyll under well water and drought conditions

\begin{tabular}{|c|c|c|c|c|c|c|}
\hline \multirow[t]{2}{*}{ Treatments } & \multicolumn{2}{|c|}{$\begin{array}{l}\text { Chlorophyll a } \\
\text { (mg/g fresh wt. } \\
\text { leaf) }\end{array}$} & \multicolumn{2}{|c|}{$\begin{array}{l}\text { Chlorophyll b } \\
\text { (mg/g fresh wt. } \\
\text { leaf) }\end{array}$} & \multicolumn{2}{|c|}{$\begin{array}{c}\text { Total Chlorophyll } \\
\text { (mg/g fresh wt. leaf) }\end{array}$} \\
\hline & $\begin{array}{c}\text { Well } \\
\text { water }\end{array}$ & $\begin{array}{c}40 \% \\
\text { FC }\end{array}$ & $\begin{array}{l}\text { Well } \\
\text { water }\end{array}$ & $\begin{array}{c}40 \% \\
\text { FC }\end{array}$ & $\begin{array}{l}\text { Well } \\
\text { water }\end{array}$ & $\begin{array}{l}40 \% \\
\mathrm{FC}\end{array}$ \\
\hline No Biochar & 1.97 & 1.46 & 0.59 & 0.46 & 2.56 & 1.92 \\
\hline $\begin{array}{l}\text { Biochar }(25 \mathrm{t} \\
\left.\mathrm{ha}^{-1}\right)\end{array}$ & 2.01 & 1.56 & 0.65 & 0.51 & 2.66 & 2.07 \\
\hline $\begin{array}{l}\text { Biochar }(50 \text { t } \\
\left.\text { ha }^{-1}\right)\end{array}$ & 2.02 & 1.78 & 0.86 & 0.67 & 2.88 & 2.45 \\
\hline $\begin{array}{l}\text { Biochar (100 t ha } \\
\text { 1) }\end{array}$ & 1.98 & 1.70 & 0.70 & 0.56 & 2.68 & 2.26 \\
\hline $\begin{array}{l}\text { LSD }_{(0.05)} \\
\text { CV }(\%)\end{array}$ & \multicolumn{2}{|c|}{ NS } & \multicolumn{2}{|c|}{0.26} & \multicolumn{2}{|c|}{ NS } \\
\hline
\end{tabular}

\section{Proline content}

The proline content in leaf of soybean plants significantly increased under drought stress (Fig.3). These results are in accordance with Abass and Mohamed (2011) who reported that the drought condition caused significant increase in the proline and soluble sugars content in shoot of common bean plants. In addition, the proline content significantly increased in leaf of soybean plants when the soil was treated with the different doses of biochar as compared with drought stressed plants and control plants.

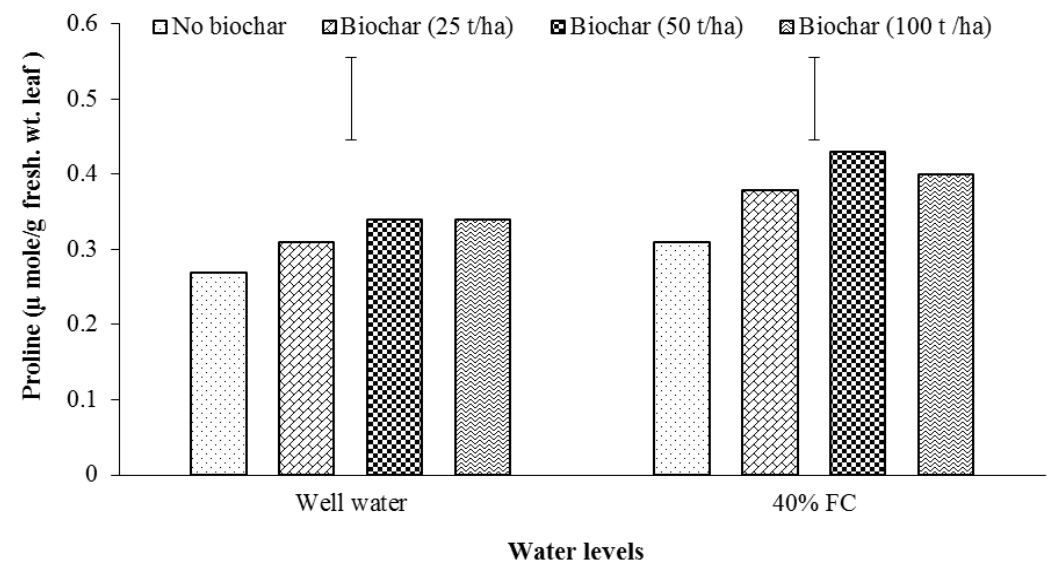

Fig. 3. Effects of poultry litter biochar on proline content under well watered and drought conditions. Bars indicate LSD at $5 \%$ level. 
Mannan et al.

In well watered condition proline content increased by 14.81 and $25.92 \%$ when biochar was applied as 25 and $50 \mathrm{t} \mathrm{ha}^{-1}$, respectively compare to no biochar application. On the other hands it was 22.58 and $38.70 \%$ compare to no biochar application when biochar was applied at the same doses under drought condition. But in case of biochar dose $100 \mathrm{t} \mathrm{ha}^{-1}$ does not follow the same increasing trend both water regimes. In this respect, the protection of soybean plants against drought stress by application of biochar is believed to be caused indirectly as a result of its effect on proline accumulation which play a protective role as scavenges of ROS, resulted in improved adaptation ability and growth of plants under drought conditions (Tbrkan and Demiral, 2009). Also, Proline can act as a signaling molecule to modulate mitochondrial functions, influence cell proliferation or cell death and trigger specific gene expression, which can be essential for plant recovery from stress (Szabados and Savoure, 2010).

\section{Seed yield and yield attributes}

Water deficit stress decreased number of pod significantly compared to well watered condition (Table 2). Application of biochar increased pod number under well watered and water deficit conditions. In well watered condition, maximum number of pod/plant was obtained (42.67), when biochar was applied @ $50 \mathrm{t} \mathrm{ha}^{-1}$, followed by biochar rate 25 and $100 \mathrm{t} \mathrm{ha}^{-1}$ and it was lowest in no biochar application. On the other hand, in water deficit condition maximum number of pod/plant was obtained (26.67), when biochar was applied @ $50 \mathrm{t} \mathrm{ha}^{-1}$, followed by biochar 100 and $25 \mathrm{t}$ $\mathrm{ha}^{-1}$ and it was lowest in no biochar application. A positive effect of biochar under water stress condition was found in case of number of seed/plant, seed weight as well as seed yield of soybean. Highest seed yield was obtained when biochar was applied @ $50 \mathrm{t} \mathrm{ha}^{-1}$ under water stress condition. Drought stress in soybean reduced total seed yield reported by Frederick et al. (2001). Biochar can increase the cation exchange capacity of soils (Liang et al., 2006), soil pH (Vaccari et al., 2011), and water holding capacity (Laird et al., 2010), which would improve nutrient and water availability in the soils and thereby improve growing conditions for plants. Some other studies have found increased above- and below-ground biomass with biochar addition (Kammann et al., 2011; Vaccari et al., 2011) as well as increased plant height and leaf area (Graber et al., 2010) which ultimately helps to increase grain yield of crops.

Table 2. Effect of poultry litter biochar on seed yield and yield components under water deficit stress

\begin{tabular}{|c|c|c|c|c|c|c|c|c|}
\hline \multirow[t]{2}{*}{ Treatments } & \multicolumn{2}{|c|}{$\begin{array}{l}\text { Number of } \\
\text { pod plant }\end{array}$} & \multicolumn{2}{|c|}{$\begin{array}{l}\text { Number of } \\
\text { seed pod }\end{array}$} & \multicolumn{2}{|c|}{$\begin{array}{l}\text { 100- seed } \\
\text { weight (g) }\end{array}$} & \multicolumn{2}{|c|}{ Seed yield plant } \\
\hline & $\begin{array}{l}\text { Well } \\
\text { water }\end{array}$ & $\begin{array}{c}40 \% \\
\text { FC }\end{array}$ & $\begin{array}{l}\text { Well } \\
\text { water }\end{array}$ & $\begin{array}{c}40 \% \\
\mathrm{FC}\end{array}$ & $\begin{array}{l}\text { Well } \\
\text { water }\end{array}$ & $\begin{array}{c}40 \% \\
\mathrm{FC}\end{array}$ & $\begin{array}{l}\text { Well } \\
\text { water }\end{array}$ & $\begin{array}{l}40 \% \\
\text { FC }\end{array}$ \\
\hline No Biochar & 38.67 & 19.67 & 1.53 & 1.85 & 10.77 & 10.12 & 5.36 & 3.74 \\
\hline Biochar $\left(25 \mathrm{t} \mathrm{ha}^{-1}\right)$ & 41.33 & 18.67 & 2.11 & 1.39 & 9.87 & 12.12 & 8.62 & 3.88 \\
\hline Biochar $\left(50 \mathrm{t} \mathrm{ha}^{-1}\right)$ & 42.67 & 26.67 & 1.71 & 1.65 & 12.2 & 12.92 & 8.81 & 4.77 \\
\hline $\begin{array}{l}\text { Biochar (100 t ha } \\
\text { 1) }\end{array}$ & 41.00 & 20.33 & 2.15 & 1.25 & 11.92 & 10.35 & 10.46 & 2.63 \\
\hline LSD & & & & & & NS & & 2.71 \\
\hline CV (\%) & & & & & & 8.8 & & 7.5 \\
\hline
\end{tabular}

\section{Conclusions}

From the results of this experiment it may be concluded that biochar application in 
Alleviation of Adverse Effect of Drought Stress on Soybean (Glycine max. L.) By Using Poultry Litter Biochar

soil can be beneficial to mitigate drought stress effect. It was found that a biochar dose $50 \mathrm{t} \mathrm{ha}^{-1}$ showed higher performance compared to the other doses.

\section{References}

Abass, S. M. and H. I. Mohamed. 2011. Alleviation of adverse effects of drought stress on common bean (Phaseolus vulgarisL.) by exogenous application of hydrogen peroxide. Bangladesh J. Bot. 41: 75-83.

Adams, M. M. Benjamin, T. J. Emery, N. C. S. J. Brouder, and K. D. Gibson.2013. The effect of biochar on native and invasive prairie plant species. Invasive Plant Sci- and Manag-. 6: 197-207.

Anjum, F., M. Yaseen, E.Rasool, A. Wahid and S. Anjum. 2003. Water stress in barley (Hordeum vulgare L.). I. Effect on morphological characters. Pak J. Agric. Sci. 40: 43-44.

Artiola, J. F., C. Rasmussen and R. Freitas. 2012. Effects of a biochar- amended alkaline soil on the growth of romaine lettuce and bermudagrass. Soil Sci. 177: 561-570.

Asai, H., B. K. Samson, H. M. Stephan, K. Songyikhangsuthor, K. Homma, Y. Kiyono, Y. Inoue, T. Shiraiwa and T. Horie. 2009. Biochar amendment techniques for upland rice production in Northern Laos:1. Soil physical properties, leaf SPAD and grain yield. Field Crops Res.111: 81-84.

Bhatt, R. M. and N. K. Rao. 2005. Influence of pod load response of okra to water stress. Indian J. Plant Physiol. 10: 54-59.

Busscher, W. J., J. M. Novak, D. E. Evans, D. W. Watts, M. A. S. Niandou and M. Ahmedna. 2010. Influence of pecan biochar on physical properties of anorfolk loamy sand. Soil Sci.175: 10-14.

Chan, K. Y., L. VanZwieten, I. Meszaros, A. Downie and S. Joseph 2007. Agronomic values of green waste biochar as a soil amendment. Aust. J. Soil Res. 45: 629634.

Farooq, M., T. Aziz, S. M. A. Basra, M. A. Cheema and H. Rehamn. 2008. Chilling tolerance in hybrid maize induced by seed priming with salicylic acid, J. Agron. Crop Sci. 194: 161-168.

Frederick, J. R., C. R. Camp and P. J. Bauer. 2001. Drought-stress effects on branch and main stem seed yield and yield components of determinate soybean, Crop Sci. 41:759-763.

Gaskin, J. W., R. A. Speir, K. Harris, K. C. Das, R. D. Morris, L. A. Lee and D. S. Fisher. 2010. Effect of peanut hull and pine chip biochar on soil nutrients, corn nutrient status, and yield. Agron. J. 102: 623-633.

Glaser, B., J. Lehmann and W. Zech. 2002. Ameliorating physical and chemical properties of highly weathered soils in the tropics with charcoal - a review. Biol. Fertil. Soils. 35: 219-230.

Gomez, K. A. and A. A. Gomez. 1984. Statistical Procedure for Agricultural Research, International Rice Research Institute, John Wiley and Sons, NewYork, Chickester, Brisbane,Toronto, Singapore. Pp. 139-240. 
Mannan et al.

Graber, E. R., Y. M. Harel and M. Kolton. 2010. Biochar impact on development and productivity of pepper and tomato grown in fertigated soil less media. Plant Soil. 337: 481- 496.

Hogan, M. C. 2011. "Respiration". Encyclopedia of Earth.Eds. Mark McGinley and C. J. Clevel and. National Council for Science and the Environment. Washington, D. C.

Jaleel, C. A., P. Manivannan, G. M. A. Lakshmanan, M. Gomathinayagam and R. Panneerselvam. 2008. Alterations in morphological parameters and photosynthetic pigment responses of Catharanthus roseus under soil water deficits. Colloids Surf. B. Biointerfaces. 61: 298-303.

Kammann, C., S. Linsel, J. GLAling and H. W. Koyro. 2011. Influence of biocharon drought tolerance of Chenopodium quinoa Willd and on soil-plantrelations. Plant Soil. 345: 195-210.

Karhu, K., T. Mattila, I. Bergstrum and K. Regina. 2011. Biochar addition to agricultural soil increased $\mathrm{CH}_{4}$ uptake and water holding capacity-results from a short-term pilot field study. Agric. Ecosyst. Environ. 140: 309-313.

Kusaka, M., M. Ohta and T. Fujimura. 2005. Contribution of inorganic components to osmotic adjustment and leaf folding for drought tolerance in pearl millet. Physiol. Plant. 125: 474-489.

Ladjal, M., D. Epron and M. Ducrey. 2000. Effects of drought preconditioning on thermotolerance of photosystem II and susceptibility of photosynthesis to heat stress in cedar seedlings. Tree. Physiol. 20: 1235-1241.

Laird, D. A., P. Fleming, D. D. Davis, R. Horton, B. Q. Wang and D. L. Karlen. 2010. Impact of biochar amendments on the quality of a typical Midwestern agricultural soil. Geoderma. 158: 443-449.

Lehmann, J. 2006. Biochar sequestration in terrestrial ecosystems: a review. Mitig. Adapt. Strateg. Glob. Chang.11: 403-427.

Lehmann, J., J. Gaunt and M. Rondon. 2006. Biochar sequestration in terrestrial ecosystems-A review. Mitigation and Adaptation Strategies for Global Change. 11(2): 403-427.

Lehmann, J. and S. Joseph. 2009. Biochar for environmental management: an introduction. In: J. Lehmann and S. Joseph (eds) Biochar for environmental management, science and technology. Earthscan. London. Pp. 1-12.

Liang, B., J. Lehmann, D. Solomon, J. Kinyangi, J. Grossman, B. O"Neill, J O. Skjemstad, J. Thies, F. J. Luizao, J. Petersen and E. G. Neves. 2006. Black carbon increases cation exchange capacity insoils. Soil. Sci. Soc. Am. J. 70: 7191730. Moussa, H. R. 2011. Low dose of gamma irradiation enhanced drought tolerance in soybean. Acta. Agro. Hung. 59: 1-12.

Nielsen, D. C. and N. O. Nelson. 1998. Black bean sensitivity to water stress at various growth stage. Crop. Sci. 38: 422-427.

Peng, X., L. L. Ye, C. H. Wang. H. Zhou and B. Sun. 2011. Temperature and duration dependent rice straw-derived biochar: Characteristics and its effects on soil properties of anultisolin southern china. Soil Tillage Res. 112: 159-166.

Rohbakhsh, H. 2013. Alleviating adverse effects of water stress on growth and yield of forage sorghum by potassium application. Adv. Environ. Biol. 7(1): 40-46.

Shao, H. B., L. Y. Chu, C. A. Jaleel and C. X. Zhao. 2008. Water deficit stressinduced anatomical changes in higher plants. CR. Biol. 331: 215-225.

Shenkut, A. A. and M. A. Brick. 2003. Traits components in common bean associated 
Alleviation of Adverse Effect of Drought Stress on Soybean (Glycine max. L.) By Using Poultry Litter

Biochar

with dry edible bean (Phaseolus vulgaris L.) productivity under diverse soil moisture environments. Euphytica. 133: 339-347.

Siddique, M. R. B., A. Hamid and M. S. Islam. 2001. Drought stress effects on water relations of wheat. Bot. Bull. Acad.Sinica.41: 35-39.

Szabados, L. and A. Savourй. 2010. Proline: a multifunctional amino acid. Trends. Plant. Sci. 15: 89-97.

Terzi, R., A. Sa

ğlamsoN. dKoutghtht H. Nar and stress on photochemical efficiency of photosystem II and anti-oxidant enzyme activities of Phaseolus vulgaris cultivars. Turk. J. Bot. 34: 1-10.

Tbrkan, I. and T. Demiral. 2009. Recent developments in understanding salinity tolerance. Environ. Exp. Bot. 67: 2-9.

Vaccari, F. P., S. Baronti and E. Lugato. 2011. Biochar a sastrategy to sequester carbon and increase yield in durum wheat. Eur. J. Agron. 34: 231-238.

Witham, F. H., D. F. Blaydes and R. M. Devlin. 1986. Chlorophyll absorption spectrum and quantitative determinations. In. Exercise in Plant Physiology. Second edition. Boston. pp. 128-131.

Younis, M. E., O. A. El-Shahaby, S. A. Abo-Hamedand A. H. Ibrahim. 2000. Effects of water stress on growth, pigments and ${ }_{14} \mathrm{CO}$ assimilation in three sorghum cultivars. J. Agron. Crop. Sci. 185: 73-82. 